\title{
The Dutch factor content of human and physical capital: a test of the HOV model
}

Citation for published version (APA):

Cörvers, F., \& Reininga, T. (1998). The Dutch factor content of human and physical capital: a test of the HOV model. Researchcentrum voor Onderwijs en Arbeidsmarkt, Faculteit der Economische

Wetenschappen. ROA Research Memoranda No. 1E https://doi.org/10.26481/umaror.199801E

Document status and date:

Published: 01/01/1998

DOI:

10.26481/umaror.199801E

Document Version:

Publisher's PDF, also known as Version of record

\section{Please check the document version of this publication:}

- A submitted manuscript is the version of the article upon submission and before peer-review. There can be important differences between the submitted version and the official published version of record.

People interested in the research are advised to contact the author for the final version of the publication, or visit the DOI to the publisher's website.

- The final author version and the galley proof are versions of the publication after peer review.

- The final published version features the final layout of the paper including the volume, issue and page numbers.

Link to publication

\footnotetext{
General rights rights.

- You may freely distribute the URL identifying the publication in the public portal. please follow below link for the End User Agreement:

www.umlib.nl/taverne-license

Take down policy

If you believe that this document breaches copyright please contact us at:

repository@maastrichtuniversity.nl

providing details and we will investigate your claim.
}

Copyright and moral rights for the publications made accessible in the public portal are retained by the authors and/or other copyright owners and it is a condition of accessing publications that users recognise and abide by the legal requirements associated with these

- Users may download and print one copy of any publication from the public portal for the purpose of private study or research.

- You may not further distribute the material or use it for any profit-making activity or commercial gain

If the publication is distributed under the terms of Article $25 \mathrm{fa}$ of the Dutch Copyright Act, indicated by the "Taverne" license above, 


\title{
The Dutch Factor Content of Human and Physical Capital: A Test of the HOV Model
}

\author{
ROA-RM-1998/1E \\ Frank Cörvers* and Ted Reininga**
}

\begin{abstract}
The paper tests the validity of the Heckscher-Ohlin-Vanek (HOV) theorem of international trade for the Netherlands by comparing the true with the trade-revealed factor endowments of human and physical capital. The factor content analysis shows that the Netherlands is abundant in producer durables and low-skilled labour and is poor in intermediate and highly-skilled labour and structures. These findings are in line with the true Dutch factor endowments relative to 20 other industrialised countries. This confirms the HOV theorem in the Dutch case. Furthermore, the paper shows that sector-specific factor inputs can be used in a cross-section regression analysis to reveal the factor abundances and factor scarcities of the Netherlands, provided that all sectors are included in the analysis.
\end{abstract}

Keywords: factor content, human capital, international trade.

* Statistics Netherlands, Kloosterweg 1, 6412 CZ Heerlen, The Netherlands

Phone: + 31455707516

E-mail: FCVS@cbs.nl

** CPB Netherlands Bureau for Economic Policy Analysis, Van Stolkweg 14, 2585 JR The Hague, The Netherlands

Phone: + 31703383460

E-mail: F.K.Reininga@cpb.nl

Research Centre for Education and the Labour Market

Maastricht University

Maastricht, August 1998 
ISBN 90-5321-245-0

Sec98.149/FC 


\section{Contents}

Pages

1 Introduction 1

2 Background of factor content studies 3

3 True versus trade-revealed factor endowments $\quad 8$

4 Using the HOV model with sector-specific factor inputs 12

5 Conclusions $\quad 18$

$\begin{array}{ll}\text { References } & 18\end{array}$

$\begin{array}{ll}\text { Appendix A } & 23\end{array}$

$\begin{array}{ll}\text { Appendix B } & 25\end{array}$

$\begin{array}{lr}\text { Appendix C } & 29\end{array}$ 


\section{Introduction 1}

In this paper the Heckscher-Ohlin-Vanek (HOV) model is tested in an empirical analysis of Dutch trade performance. The explanatory power of both country-specific and sector-specific determinants of Dutch trade performance is considered in the HOV model. Leamer and Bowen (1981) have proved that the net trade of sectors is dependent on country-specific factor endowments rather than on sector-specific factor inputs. ${ }^{2}$ However, empirical studies often show poor results if, in accordance with the HOV model, net trade flows at sector level are explained by country-specific factor endowments (e.g. Bowen, Leamer and Sveikauskas, 1987, and Bowen and Sveikauskas, 1992).

The paper attempts to cast new light on both the country-specific and the sector-specific determinants of trade performance by carrying out a factor content analysis of Dutch trade. Five production factors are distinguished, namely the human capital factors of low, intermediate and highly-skilled labour, and the physical capital factors of structures and producer durables. The trade-revealed factor endowments and the sector-specific factor inputs of these production factors are calculated by taking account of their factor contents in net exports and domestic consumption. ${ }^{3}$ The trade-revealed factor endowments of the production factors are ranked according to their abundance within the Netherlands. The HOV model will be tested by comparing this rank order to the rank order of the true factor endowments of these production factors in the Netherlands. The true factor endowments of the Netherlands represent the real availabilities of low, intermediate and highly-skilled labour and two components of physical capital, i.e. structures and producer durables, relative to those of 20 other industrialised countries.

Four issues may be particularly relevant when testing the HOV model. These issues can be found in Leamer and Bowen (1981) and Bowen et al. (1987). Firstly, a proper test of the HOV theorem necessarily involves the triad of trade, input-output requirements and factor endowments. The HOV theorem equates the factors embodied in a country's net exports, which are calculated by using input-output requirements, to the country's excess supplies of factor endowments. Therefore the HOV theorem is tested by measuring separately trade, input-output requirements and factor endowments. Secondly, countries may have different input-output requirements (i.e. technological differences), whereas the HOV theorem assumes identical input-output requirements between countries. Although this may seriously affect the results, it is important to note that input-output requirements are relatively similar for

1. This paper is partly based on Cörvers and Reininga (1996). We would like to thank Lex Borghans, Andries De Grip, Hans Heijke, Steven J. Keuning, Peter Van Der Ven and Adriaan Van Zon for their comments on earlier versions of the paper.

2. See also Leamer (1992) and Cörvers and De Grip (1997).

3. The sector classification used is listed in Appendix A. Furthermore, Appendix B discusses the construction of a matrix with the input-output requirements of 40 sectors, which is used for the calculation of the sector-specific factor inputs. 
industrialised countries, between which the majority of world trade takes place. ${ }^{4}$ For the Netherlands $83 \%$ of Dutch imports originated from OECD countries and $89 \%$ of Dutch exports went to OECD countries in 1990 (CBS, 1990). Thirdly, measurement errors in either the factor contents or the factor endowments may seriously affect the outcomes of the empirical analysis. In this paper the human and physical capital contents of net trade, production and consumption in the Netherlands are carefully calculated by using social accounting matrices and basic prices. ${ }^{5}$ Fourthly, in many empirical studies of the HOV model sector-specific factor inputs are used as the determinants of trade ${ }^{6}$ which is wrong from a theoretical point of view when applying the HOV model. However, as will be demonstrated, the results of an empirical analysis with a HOV model that uses sector-specific factor inputs may be interesting, but should be interpreted with care. It will be shown that the impact of the sector-specific factor inputs on trade performance reveals the abundances of the production factors only if all sectors in the Netherlands are included in the empirical analysis. Therefore the analysis in this paper covers all sectors in the Netherlands.

For the Netherlands an analysis with sector-specific inputs as explanatory variables for trade performance was carried out by Fortune (1976), Koekkoek et al. (1978) and Hulsman-Vejsová and Koekkoek (1980). These studies have conducted a cross-section regression analysis of Dutch manufacturing sectors to reveal the comparative advantages of the Dutch industry. The results of these and other studies on Dutch comparative advantage, reviewed by Koekkoek and Mennes (1984), often point to different and sometimes even opposite conclusions with respect to the revealed comparative advantage of the Dutch manufacturing sectors. ${ }^{7}$ From the HOV model follows that a country has a revealed comparative advantage in the production of a good (represented by a sector), if the country has an abundance of the production factor that is used intensively for the production of that good. Based on their review of studies Koekkoek and Mennes (1984) conclude that, among other things, the Dutch manufacturing sectors have a revealed comparative advantage in skill-intensive products, whereas the physical-capital intensity does not contribute to the revealed comparative advantage of the Dutch manufacturing sectors. It will be shown that the conclusions on Dutch comparative advantage drawn by Koekkoek and Mennes (1984) may be misleading, because they have not included all sectors in the Netherlands.

4. See OECD (1987) and CPB (1993). James and Elmslie (1996) and Cörvers and De Grip (1997) have the same argument as mentioned above for the failure of the HOV model in many other empirical studies.

5. Appendix $B$ describes in detail the method of data generation and factor content calculations.

6. See e.g. Baldwin (1971), Katrak (1973), Branson and Monoyios (1977), Stern and Maskus (1981) and Courakis (1991).

7. To explain this, Koekkoek and Mennes refer to the differences in these studies with respect to the explanations of the structure of international trade, the aims of the studies, the measurements of relevant concepts, the use of the sets of explanatory variables, and lastly the definition of revealed comparative advantage. Even Koekkoek and Mennes themselves draw conclusions about the revealed comparative advantage of the manufacturing sectors in the Netherlands, without saying what they exactly mean by revealed comparative advantage. 
The remainder of the paper is organised as follows. The next section discusses the background of factor content studies. Section 3 discusses the trade-revealed factor endowments and the true factor endowments for the five production factors mentioned above. The rank orders of true and trade-revealed factor endowments are compared in order to test the HOV theorem for the Netherlands. Section 4 discusses the input of sector-specific factors in the manufacturing sectors only, and carries out regression analyses to explain the trade performance of both manufacturing and non-manufacturing Dutch sectors by sector-specific factor inputs. Section 5 presents the conclusions.

\section{Background of factor content studies}

One of the theorems following from the HOV model, the Heckscher-Ohlin-Vanek theorem, states that countries tend to export the factor services of their relatively abundant production factors and tend to import the factor services of their relatively scarce production factors. ${ }^{8}$ It emphasises that factor services are exchanged through trade. The traded goods that embody or contain the services of the production factors merely conduct that exchange.

The assumptions of the HOV model are (Leamer, 1980) (a) perfect competition in the goods and factors markets, (b) zero cost of transport of commodities and no other impediments to trade, (c) immobility of production factors between countries, but complete mobility of production factors between sectors within a country, (d) identical input-output (technology) relations in all countries, (e) production functions showing constant returns to scale, (f) factor price equalisation across countries, ( $g$ ) equal numbers of factors and goods, (h) consumers maximise their identical homothetic utility functions.

In particular the assumptions of identical input-output relations and factor price equalisation across countries may be crucial for the relevance of the HOV model. Deardorff (1982) shows that if both of these assumptions are met, factor intensity reversals cannot occur. ${ }^{9}$ These assumptions of the HOV model are more valid for a group of industrialised countries than for a mixed group of industrialised and developing countries. ${ }^{10}$ Therefore the HOV model may usefully be applied to a group of industrialised countries, as in for example Cörvers and De Grip (1997) and James and Elmslie (1996). Moreover, models assuming constant returns to scale, such as the HOV model, must be distinguished from models that allow for economies of scale. Economies of scale are relevant for explaining intra-industry trade between

8. The use of the verb 'tend' indicates that this theorem holds on average (see Deardorff, 1982, and Forstner, 1985).

9. This implies that a good that is produced with a capital intensive production technique in a developed country, is produced with the same capital intensive production technique in a less developed country, and not with a labour intensive production technique.

10. Generalisations of the HOV theorem without assuming factor price equalisation are found in Brecher and Choudhri (1982), Deardorff (1982) and Helpman (1984). 
industrialised countries (see also Deardorff, 1984). Following Leamer (1984), who also uses the HOV model, this paper does not incorporate such economies into the model because the model explains net trade, i.e. exports minus imports, instead of exports and imports separately. ${ }^{11}$ As for other assumptions of the HOV model, Leamer concludes that, if the assumptions with regard to trade impediments, international factor mobility, non-traded and intermediate goods, transportation costs, factor market distortions and consumer preference dissimilarities are not fulfilled, outcomes from the HOV model are not seriously affected. ${ }^{12}$

One major advantage of factor content analysis is that it requires less restrictive assumptions than an analysis based on the commodity version of the Heckscher-Ohlin theorem. The multidimensional case of the commodity version states that countries tend to export those goods which require relatively great inputs of their relatively abundant production factors and tend to import those goods which require relatively great inputs of the production factors in which they are relatively poor. This multidimensional case has been difficult to prove (Deardorff, 1982 and 1984) and does not generate clear or correct predictions about the trade flows of goods (Bowen and Sveikauskas, 1992). Moreover, in factor content analysis, in contrast to analysis based on the commodity version of the HOV theorem, the number of traded goods may be either equal to or larger than the number of production factors (as one would expect). Under this less restrictive assumption, the commodity composition of trade flows is not uniquely determined, whereas the factor services incorporated in the exports and imports are uniquely determined. In factor content analysis it is not even necessary to assume factor price equalisation or identical and homothetic preferences (see e.g. Grossman and Helpman, 1991).

Factor content analysis has been used as a valuable tool to obtain empirical evidence of the impact of human capital on trade performance in, for example, Clifton and Marxsen (1984), Webster (1993), Maskus et al. (1994), Reininga (1994) and Webster and Gilroy (1995). However, only Webster (1993) and Reininga (1994) measure human capital by distinguishing educational categories of labour, which has to be preferred instead of measuring human capital by discounted sector-wage differentials or by distinguishing occupational categories of labour. Moreover, factor content studies of Dutch trade give ambiguous results with regard to the relevance of human and physical capital for Dutch trade. Hamilton and Svensson (1984) and Bowen et al. (1987) calculate the factor content of trade flows for many countries, including the Netherlands. They apply the input-output requirements of Sweden and the United States, respectively, to the Netherlands. The former study shows that the capital content of Dutch exports is larger than the capital content of Dutch imports for bilateral trade flows

11. According to Leamer (1984) "The apology is that the level of aggregation and the use of net exports rather than exports and imports separately reduce the possibility that scale effects are important".

12. Moreover, the results of the HOV model are less distorted by trade barriers now than they once were, as the barriers are gradually broken down by free trade agreements. 
between the Netherlands and the main regions in the world during the period 1970 to $1980 .{ }^{13}$ Unfortunately this study does not distinguish between physical and human capital. ${ }^{14}$ The study by Bowen et al. (1987) shows that, if trade flows are corrected for the Dutch trade balance deficit, the Netherlands imports the factor services of physical capital and exports the factor services of seven different occupational categories of labour in $1967 . .^{15}$

Next, the theoretical framework of the factor content studies is clarified. Net exports of country i equal the difference between production and consumption, $T_{i}=Q_{i}-C_{i}$, in which $T, Q$ and $C$ represent the $n \times 1$ vectors of net trade (i.e. exports minus imports), production and consumption, respectively, ${ }^{16}$ and where $n$ represents the number of goods that are internationally freely mobile. Pre-multiplying the last equation with the $m \times n$ input-output matrix $A$, in which $m$ represents the number of production factors that are internationally perfectly immobile, leads to an equation in which factor services embodied in net exports are equal to the difference between the supply of factor services and the use of factor services, thus $A T_{i}$ $=A\left(Q_{i}-C_{i}\right)$. Define $F_{i}$ as the $m \times 1$ vector of factor services of net trade, which equals $A T_{i}$ by definition. Moreover, define $V_{i}$ as the vector of factor endowments, which equals $A Q_{i}$ by definition. Lastly, due to the above assumptions, the factor content of consumption equals the share $\beta_{i}$ that country $i$ uses from the $m \times 1$ vector of total world factor endowments, $V_{w}$. This share equals the share of national income, corrected for the trade balance $B_{i}$, in total world income. In other words, $\beta_{i}=\left(G D P_{i}-B_{i}\right) / G D P_{w}$. If the above definitions and results are substituted into equation $A T_{i}=A\left(Q_{i}-C_{i}\right)$, this leads to equation (1) for a particular production factor $k$.

$$
F_{k i}=V_{k i}-\frac{\left(G D P_{i}-B_{i}\right)}{G D P_{w}} V_{k w}
$$

This equation can be rewritten as follows:

$$
\frac{F_{k i} / V_{k w}}{G D P_{i} / G D P_{w}}-\frac{B_{i}}{G D P_{i}}=\frac{V_{k i} / V_{k w}}{G D P_{i} / G D P_{w}}-1
$$

The right-hand side of this equation reflects the relative true factor endowments of country $i$, which will be used in Section 3 to calculate the Dutch factor endowments of human and physical capital relative to twenty other industrialised countries. If the right-hand side is positive

13. This does not hold for the trade of the Netherlands (and most other countries) with Latin America in the Hamilton and Svensson (1984) study.

14. Hamilton and Svensson (1984) calculate the factor content by using the labour productivity level. They assume that the labour productivity level measures the sum of human and physical capital intensity.

15. Another interesting factor content analysis of the Netherlands by Reininga (1994) will be discussed below.

16. In this paper we refer to the terms 'production' and (domestic) 'consumption' instead of the empirically correct terms 'value added' and 'domestic final use', respectively, since the use of the former terms is common practice in factor content studies. 
for a particular factor $k$ in country $i$, then the country has a true abundance of this factor. The left-hand side of the equation reflects the trade-revealed factor endowments indicated by a country's net trade, and will be used for the factor content analysis of this paper. If the lefthand side of equation (2) is positive, then country $i$ has a revealed abundance of this factor. This implies that country $i$ has a revealed comparative advantage in goods that make intensive use of factor $k$. The left-hand side of the equation is corrected for the trade balance, so that a country with for example a positive trade balance has both positive and negative traderevealed factor endowments. The relationship between the true factor abundance and the trade-revealed factor abundance is a consequence of the HOV theorem, which implies that countries that have an abundance of a particular production factor $k$ should have net exports of the factor services of factor $k$.

From the left-hand side of the equation, it follows that a country is more abundant in factor $k$ than in factor $k^{\prime}$ if the following inequality holds.

$$
\frac{F_{k i}}{V_{k w}}>\frac{F_{k^{\prime} i}}{V_{k^{\prime} w}}
$$

Since $V_{k i}=(A C)_{k i} / \beta_{i}$ and $(A C)_{k i}$ represents the domestic consumption of factor $k$, which is renamed $D_{k i}$ for convenience, inequality (3) can be rewritten to give the inequality that will be used in the empirical analysis of this paper.

$$
\frac{F_{k i}}{D_{k i}}>\frac{F_{k^{\prime} i}}{D_{k^{\prime} i}}
$$

Inequality (4) implies that if the ratio of the factor content of net trade to the factor content of domestic consumption, for a production factor $k$ such as highly-skilled workers, is larger than the same ratio for production factor $k^{\prime}$, for example low-skilled workers, then highly-skilled workers are more abundant than low-skilled workers in country $i$. The rank order of the factor content ratios of net trade relative to consumption indicates the revealed factor abundances of the production factors within a country: the larger the ratio, the larger the revealed factor abundance.

In contrast to the two above-mentioned empirical studies, Reininga (1994) uses Dutch inputoutput data. He finds that in 1990 the Dutch export/import ratio for the factor content of human capital hardly differed from the ratio for homogeneous labour, from which he concludes that the Dutch economy is not as human capital intensive as would be expected. Reininga (1994) also finds the unexpected result that Dutch exports are less intensive in physical capital than Dutch imports. However, his empirical analysis follows the same approach as Leontief's (1953), who compares the physical capital intensity of exports to the physical capital intensity of imports. On the contrary, equation (4) above shows that the factor intensity of net exports should be compared to the factor intensity of consumption to reveal factor abundance of 
physical capital.

It is relatively easy to show that the factor abundance condition of inequality (4) is only similar to that of Leontief (1953) if the important condition is satisfied that the net exports of the factor services of factor $k$ are opposite in sign to the net exports of the factor services of factor $k^{\prime}$ (see also Leamer, 1980). Suppose that factor $k$ is more abundant than factor $k$ '. By definition, $F_{k i}$ equals $X_{k i}-M_{k i}$ and $F_{k^{\prime}}$ equals $X_{k^{\prime}}-M_{k^{\prime}}$, with $X$ representing the factor ( $k$ or $k^{\prime}$ ) content of exports and $M$ representing the factor ( $k$ or $k^{\prime}$ ) content of imports. Under the condition that $F_{k i}$ and $F_{k^{\prime} i}$ are opposite in sign, it follows that $X_{k i}-M_{k i}>0$ and $X_{k^{\prime}}-M_{k^{\prime}}<0 .{ }^{17}$ Thus, $X_{k i} / M_{k i}>1$ and $X_{k^{\prime}} / M_{k^{\prime}}<1$, and therefore $X_{k i} / M_{k i}>X_{k^{\prime}} / M_{k^{\prime} r}$ This results in Leontief's factor abundance inequality (5).

$$
\frac{X_{k i}}{X_{k^{\prime} i}}>\frac{M_{k i}}{M_{k^{\prime} i}}
$$

Suppose that factor $k$ represents physical capital and factor $k^{\prime}$ represents labour, as in Leontief's study. If the factor services of physical capital embodied in net exports are positive and the factor services of labour embodied in net exports are negative, then the above inequality, which is used by Leontief, implies that the capital per man embodied in exports exceeds the capital per man embodied in imports. Leontief finds that the physical capital intensity of exports is smaller that the physical capital intensity of imports for the United States in 1947, which is contrary to the expectations and is known as the Leontief paradox. However, if the assumption that the factor services of factor $k$ embodied in net exports are opposite in sign to the factor services of factor $k^{\prime}$ embodied in net exports is not satisfied, the Leontief inequality (5) is not the proper test of the HOV theorem. Indeed, the condition that the factor services of physical capital and labour embodied in net exports are opposite in sign, is not satisfied for the 1947 U.S. data in Leontief's study, nor for the 1990 Dutch data in the study by Reininga (1994). ${ }^{18}$ In other words, for these studies it holds that even if physical capital is revealed to be abundant relative to labour according to inequality (4), the capital intensity of exports can be smaller than the capital intensity of imports. Leamer (1980) solves the Leontief paradox by rewriting inequality $(4)^{19}$ and showing that the physical capital intensity of net exports is larger than the physical capital intensity of consumption for the 1947 U.S. data used in Leontief's empirical analysis. Since Reininga (1994) follows Leontief (1953), Reininga's conclusions with regard to the human and physical capital content of Dutch trade may be wrong for the same reason. ${ }^{20}$

17. Remember that factor $k$ is more abundant than factor $k^{\prime}$.

18. Reininga (1994) confirms the Leontief paradox for the Netherlands, which implies that the Netherlands imports capital-intensive goods and exports labour-intensive goods, which is analogous to the results for the United States in Leontief's study.

19. Inequality (4) can be easily rewritten by dividing both sides by $F_{k i}$ and multiplying both sides by $D_{k i}$. Since the United States is a net exporter of both capital and labour services in 1947, inequality (4) is not changed by negative multiplication.

20. This also holds for the study by Hamilton and Svensson (1984). 


\section{True versus trade-revealed factor endowments}

Factor content analysis of trade refers to measures of trade-revealed factor endowments, which is based on the left-hand side of equation (2). The right-hand side of equation (2) measures the true factor endowments. Both methods of measuring the factor endowments of a country are examined in this section. The factor content analysis includes the 40 sectors of the whole Dutch economy, including the 17 manufacturing sectors. ${ }^{21}$ The true factor endowments of the Netherlands are calculated relative to 20 OECD countries. For this reason the true factor endowments are called the relative true factor endowments. Equation (2) indicates that the two definitions of factor abundances must correspond to each other. If the factor contents of trade flows are not in line with the relative true factor endowments, then the HOV theorem must be rejected. By using data at the country level, this section shows the abundant and scarce factor endowments of the Netherlands, and whether the HOV theorem is confirmed or rejected for the case of the Netherlands.

The data used for the two methods of measurement are different from each other, with regard to both sources and definitions. ${ }^{22}$ Firstly, the relative factor endowments of low-skilled, intermediate-skilled and highly-skilled labour are calculated from the OECD data $(1992,1993)$ and refer to the level of educational attainment of the whole population between 15 and 64 years old. The factor content data are drawn from national statistics (see Appendix B) and refer to the wage sum of the three skill categories of the working population. ${ }^{23}$ Secondly, relative factor endowments of physical capital (producer durables and structures) are calculated from the Penn World Tables (mark 5.6) and refer to the stock of physical capital. On the contrary, factor content analysis uses depreciation flows drawn from Dutch national statistics.

\section{True factor endowments}

Table 1 presents the true factor endowments of low-skilled, intermediate-skilled and highlyskilled labour, producer durables and structures for the Netherlands relative to 20 OECD countries. The right-hand side of equation (2) indicates that the relative true factor

21. See Appendix A for the sector classification that is used in this paper. This sector classification is based upon the SBI classification of Statistics Netherlands, which is compatible with the International Standard Industrial Classification of All Economic Activities (ISIC).

22. The reference year of the data used for the true factor endowments is 1990 , whereas it is 1991 for the data used for the factor content ratios. This is not considered to be a problem, since factor endowments and trade patterns generally change only slightly over time.

23. Nevertheless, the definitions of the levels of educational qualifications are similar in the two data sources. Low-skilled labour refers to ISCED 0/1/2, intermediate-skilled labour refers to ISCED 3 and highly-skilled labour refers to ISCED 6/7. See OECD (1995) for the Dutch educational system in an international context. 
endowments, $\left(V_{k} / V_{k w}\right) /\left(G D P_{k} / G D P_{k w}\right),{ }^{24}$ will be larger than one where there is factor abundance. Table 1 shows that only low-skilled labour is abundant in the Netherlands. A relative true factor endowment smaller than one indicates factor scarcity, so that we can conclude from Table 1 that intermediate-skilled labour, highly-skilled labour and structures are scarce in the Netherlands. Moreover, the endowment of producer durables is neither abundant nor scarce in the Netherlands, since the relative true factor endowment of producer durables equals one.

The rank order of the relative true factor endowments for the Netherlands is (from high to low): low-skilled labour, producer durables, intermediate-skilled labour, structures, highly-skilled labour. The differences between the last three relative true factor endowments are very small, whereas the relative true factor endowments of producer durables and in particular low-skilled labour are considerably larger.

Table 1

True factor endowments of low, intermediate and highly-skilled labour, structures and producer durables for the Netherlands, relative to 20 other countries, 1990
relative true factor endowment
value
ranking

$\begin{array}{lll}\text { low-skilled } & 1.14 & 1 \\ \text { intermediate-skilled } & 0.83 & 3 \\ \text { highly-skilled } & 0.81 & 5 \\ \text { structures } & 0.82 & 4 \\ \text { producer durables } & 1.00 & 2\end{array}$

Sources and notes: See Table C.1 in Appendix C.

\section{Trade-revealed factor endowments}

As indicated by equation (4), the larger the ratio between the factor content of net trade and the factor content of domestic consumption for a given production factor in a country, the larger the trade-revealed factor endowment of the production factor. ${ }^{25}$ Although the factor content ratios do not indicate factor abundance or factor scarcity, they indicate the rank order of production factors with regard to their factor abundance within a country. ${ }^{26}$ The ranking of the Dutch factor content ratios is presented for low, intermediate and highly-skilled labour and

24. National income is measured by Gross Domestic Product (1990 international prices).

25. The trade-revealed factor endowments of the Netherlands are based on net trade, which equals the exports to the rest of the world minus the imports from the rest of the world. However, the true factor endowments presented above are calculated relative to 20 other OECD countries instead of all countries of the rest of the world. This is not considered a problem, since $83 \%$ of Dutch imports was imported from OECD countries and 89\% of Dutch exports was exported to OECD countries in 1990 (CBS, 1990).

26. In this paper the trade-revealed factor endowments only have a ranking according to their factor abundance, whereas a relative true factor endowment larger than one indicates factor abundance and a relative true factor endowment smaller than one indicates factor scarcity. 
for two types of physical capital. For a more comprehensive analysis, the three skill levels of labour are also disaggregated to the seven levels of educational qualifications that are typical for the Netherlands.

Table 2 shows the factor content ratios of net exports relative to domestic consumption of all sectors of the Dutch economy. The factor ratios show that the rank order from the most abundant to the least abundant production factor in the Netherlands is as follows: producer durables, low-skilled labour, intermediate-skilled labour, structures, highly-skilled labour. ${ }^{27}$ Note that producer durables has by far the largest factor content ratio and low-skilled labour has the largest factor content ratio of the labour content ratios.

Table 2

Dutch factor contents (millions of guilders) of net exports $(F)$ and domestic consumption $(D)$, for three skill levels, all sectors, 1991

\begin{tabular}{lrrrr}
\hline Production factor $(k)$ & $F_{k}$ & $D_{k}$ & $F_{k} / D_{k}$ & ranking \\
\hline low-skilled & & & & \\
intermediate-skilled & 13,149 & 50,440 & 0.261 & 2 \\
highly-skilled & 15,166 & 79,379 & 0.191 & 5 \\
structures & 6,828 & 56,402 & 0.121 & 4 \\
producer durables & 2,696 & 18,820 & 0.143 & 1 \\
\hline
\end{tabular}

Table 3 presents the shares of low, intermediate and highly-skilled labour in the total factor content of both net exports and domestic consumption. The table shows the low share of lowskilled labour in Dutch net exports and the relative significance of highly-skilled labour in Dutch domestic consumption. Moreover, the share of the factor content of intermediate-skilled labour in the total labour content of net exports is the same as the share of intermediate-skilled labour in the total labour content of domestic consumption.

Table 3

Dutch factor content shares of low, intermediate and highly-skilled labour in the total labour content of net exports $(F)$ and domestic consumption $(D)$, all sectors, 1991

\begin{tabular}{lll} 
Skill category & $F$ & $D$ \\
\hline low-skilled & & \\
intermediate-skilled & 0.37 & 0.27 \\
highly-skilled & 0.43 & 0.43 \\
total & 0.19 & 0.30 \\
& 1.00 & 1.00
\end{tabular}

Table 4 shows results similar to those in Table 2, except that the three human capital factors have been disaggregated into seven educational categories of labour. The ratios are high for producer durables, Primary Education (BO), Preparatory Vocational Education (VBO) and

27. Note that the absolute abundance cannot by determined by the ranking of the factor content ratios. 
Lower General Secondary Education (MAVO), and low for Higher Vocational Education (HBO) and University Education (WO). The table shows moderate factor content ratios for Higher General Secondary Education and Pre-University Education (HAVO/VWO), for Intermediate Vocational Education (MBO) and for the structures component of physical capital.

Table 4

Dutch factor contents (millions of guilders) of net exports $(F)$ and domestic consumption $(D)$, for seven educational categories, all sectors, 1991

\begin{tabular}{|c|c|c|c|c|}
\hline Production factor $(k)$ & $F_{k}$ & $D_{k}$ & $F_{k} / D_{k}$ & ranking \\
\hline \multicolumn{5}{|l|}{ low-skilled } \\
\hline $\mathrm{BO}$ & 4,091 & 14,332 & 0.285 & 2 \\
\hline MAVO & 2,208 & 10,648 & 0.207 & 4 \\
\hline VBO & 6,850 & 25,461 & 0.269 & 3 \\
\hline \multicolumn{5}{|l|}{ intermediate-skilled } \\
\hline HAVO/VWO & 1,570 & 8,336 & 0.188 & 6 \\
\hline MBO & 13,596 & 71,042 & 0.191 & 5 \\
\hline \multicolumn{5}{|l|}{ highly-skilled } \\
\hline $\mathrm{HBO}$ & 4,654 & 35,787 & 0.130 & 8 \\
\hline Wo & 2,175 & 20,614 & 0.106 & 9 \\
\hline \multicolumn{5}{|l|}{ physical capital } \\
\hline structures & 2,696 & 18,820 & 0.143 & 7 \\
\hline producer durables & 8,322 & 20,803 & 0.400 & 1 \\
\hline
\end{tabular}

Note: $\mathrm{BO}=$ Primary Education, MAVO $=$ Lower General Secondary Education, VBO $=$ Preparatory Vocational Education, HAVO = Higher General Secondary Education, VWO = Pre-University Education, $\mathrm{MBO}=$ Intermediate Vocational Education, $\mathrm{HBO}=$ Higher Vocational Education, $\mathrm{WO}=$ University Education.

With regard to the ranking of the ratios of the factor services of net exports to domestic consumption, the disaggregated educational categories of labour perfectly fit in the classification of low, intermediate and highly-skilled labour. This illustrates that a more disaggregated analysis does not provide additional information and that the classification of low, intermediate and highly-skilled labour is well chosen.

\section{Comparison of true and trade-revealed factor endowments}

The next step of the analysis is to compare the rank order of the relative true factor endowments, which is shown in Table 1, to the rank order of the trade-revealed factor endowments, which is shown in Table 2. Comparing these rank orders shows that both rank orders are identical, except that the rankings of producer durables and low-skilled labour are switched. Moreover, the relative true factor endowment of producer durables in Table 1 does not indicate a true factor abundance, since it equals one, whereas producer durables has the largest trade-revealed factor abundance. To test the correlation between the rank order of the 
relative true factor endowments on the one hand, and the rank order of the trade-revealed factor endowments on the other, the Spearman's rank correlation coefficient is calculated. This rank correlation coefficient equals 0.9 and is significant at the $5 \%$ level (one-tail test). ${ }^{28}$ Therefore the null hypothesis of no correlation between these rank orders is rejected at the $5 \%$ significance level, against the alternative that the correlation between the relative true factor endowments and trade-revealed factor endowments is positive. It follows that the HOV theorem is confirmed for the case of the Netherlands.

Since producer durables is the most abundant trade-revealed factor endowment in the factor content analysis of Table 2, and the relative true factor endowment of producer durables is considerably larger than the relative true factor endowments of intermediate-skilled labour, highly-skilled labour and structures in Table 1, we conclude that the Netherlands is abundant in producer durables. From the results of both measurement methods of factor abundance, it may be concluded that low-skilled labour is also abundantly available. Furthermore, it follows from Tables 1 to 3 that the trade performance of the Netherlands, measured by exports minus imports, is dependent on the country-specific scarcity of intermediate-skilled labour, highlyskilled labour and structures. With regard to the human capital endowments, this implies that the Netherlands has a comparative advantage in goods that make intensive use of low-skilled labour, and a comparative disadvantage in goods that make intensive use of intermediate and highly-skilled labour.

\section{Using the HOV model with sector-specific factor inputs}

This section illustrates the significance of sector-specific factors for trade performance in two ways. Firstly, the factor content analysis of the last section is repeated by including the factor content of net exports and domestic consumption of the manufacturing sectors only. Secondly, two regression analyses based on the HOV model are carried out to explain how the trade performance of Dutch sectors of industry is related to the input of sector-specific factors.

\section{Factor content analysis for the manufacturing sectors}

Table 5 shows the factor content calculations of net exports and domestic consumption for the 17 manufacturing sectors of the Netherlands (see Appendix A). Contrary to the factor content ratios of the entire economy, the factor content ratios of the manufacturing sectors are larger than one. This implies that the manufacturing sectors of the Netherlands are more involved in export activities than the average Dutch sector. Moreover, the ranking of the factor content ratios for the manufacturing sectors is very different from the ranking of the factor content

28. See James and Elmslie (1996) for a similar analysis to test the HOV model in the G7 countries (Canada, France, West Germany, Italy, Japan, UK and US). Five of the seven countries have a significant correlation of the two rank orders at the $10 \%$ level. Only in France and Italy the correlations are found to be inconsistent with the HOV model. 
ratios when all sectors of the Dutch economy are included. Highly-skilled labour takes the first instead of the last position, which is now taken by low-skilled labour. The rankings of the other three factors shift one position. Although highly-skilled labour is relatively scarce in the Netherlands, the manufacturing sectors make intensive use of highly-skilled labour for the production of export goods relative to the production of goods that are consumed domestically. Highly-skilled labour clearly is an important factor input for the trade performance of the manufacturing sectors.

Table 5

Dutch factor contents (millions of guilders) of net exports $(F)$ and domestic consumption $(D)$, manufacturing sectors, 1991

\begin{tabular}{lrrrr}
\hline Production factor $(k)$ & $F_{k}$ & $D_{k}$ & $F_{k} / D_{k}$ & ranking \\
\hline low-skilled & & & & 5 \\
intermediate-skilled & 7,089 & 5,976 & 1.186 & 4 \\
highly-skilled & 8,664 & 7,045 & 1.230 & 1 \\
structures & 4,563 & 2,977 & 1.532 & 3 \\
producer durables & 1,423 & 1,093 & 1.301 & 2 \\
\hline
\end{tabular}

Table 6 shows the factor content shares of low, intermediate and highly-skilled labour in the total labour content of net exports and domestic consumption for the manufacturing sectors. The factor content shares of net exports relative to domestic consumption reflect the factor content ratios for the manufacturing sectors in Table 5. Therefore the factor content share of highly-skilled labour in net exports is larger than its factor content share in domestic consumption. Conversely, the factor content shares of low and intermediate-skilled labour in the net exports in the manufacturing sectors are lower than the shares in the factor content of domestic consumption. This is opposite to the factor content shares of low, intermediate and highly-skilled labour in net exports relative to domestic consumption of the total economy (see Table 3 of the previous section).

The above analysis of the manufacturing sectors shows that highly-skilled labour and producer durables are intensively used in net exports relative to domestic consumption. Thus highlyskilled labour and producer durables are important factor inputs for the trade performance of the Dutch manufacturing sectors. However, the analysis also shows that judging factor abundances by calculating the factor contents of net exports and domestic consumption in the manufacturing sectors can lead to completely incorrect conclusions. In other words, the factor contents of net exports and domestic consumption of the manufacturing sectors give information on the contribution of sector-specific factor inputs to trade performance rather than on the abundance of trade-revealed country-specific factor endowments.

Table 6

Dutch factor content shares of low, intermediate and highly-skilled in total labour content of net exports $(F)$ and domestic consumption $(D)$, manufacturing sectors, 1991 


$\begin{array}{lll}\text { low-skilled } & 0.35 & 0.37 \\ \text { intermediate-skilled } & 0.43 & 0.44 \\ \text { highly-skilled } & 0.22 & 0.19 \\ & & \\ \text { total } & 1.00 & 1.00\end{array}$

\section{Explaining trade performance by sector-specific factor inputs}

Table 7 presents the results of the regression analyses in which the vector of net exports $T_{i}$, adjusted for trade imbalance, is regressed on the input-output requirements given by matrix $A$ (see Section 2). Bowen and Sveikauskas (1992) refer to three issues that are relevant when estimating cross-section regressions. Firstly, the reliability of the estimated coefficients as indicators of revealed factor abundance improves if net exports per industry are corrected for the trade imbalance. This correction has been made for each of the 40 sectors by subtracting a weighted share of the trade balance surplus of the Netherlands from the net exports of each industry. The weighted shares equal the weights of domestic consumption of the industry in total domestic consumption. The signs of most of the estimated coefficients in the regression analyses of Table 7 do not change as a result of adjusting net exports in this way. Secondly, it is not clear in advance whether or not the constant term should be included in the regression analysis. Following Bowen and Sveikauskas (1992) we include a constant term. This term measures the level of net trade (imports) when there is no domestic production, in which case the factor inputs are zero. Therefore the sign of the constant term is expected to be negative. Thirdly, according to Bowen and Sveikauskas many sources of heteroscedasticity may exist. A general test for the assumption of homoscedasticity of the error terms is the White test. According to this test heteroscedasticity is not indicated for the usual ordinary least squares (OLS) regression of the above mentioned specification. ${ }^{29}$ By conducting the Park test and the Goldfeld-Quandt test (see e.g. Gujarati, 1988) for each of the explanatory variables, it is found that the heteroscedasticity of the error terms is significantly dependent on the physical capital measure of producer durables. However, since other sources of heteroscedasticity may also exist, we follow Bowen and Sveikauskas and use a covariance matrix that is heteroscedasticity consistent (White covariance matrix). This improves in general the significance of the estimated coefficients in our regression analyses.

The first column of Table 7 presents the results of the regression analysis with sector-specific

29. The White heteroscedasticity test is also a general test for model misspecification. This test does not indicate that the omission of land input and other natural resources as explanatory variables hampers the results of Table 7 seriously. See White (1980) for both the White test and the White covariance matrix. 
factor inputs as the explanatory variables for the trade performance of the manufacturing sectors. Analogous to the analysis of the rank order of factor abundances for the manufacturing sectors that has been carried out above, the signs of the estimated coefficients should not be interpreted as an indication of factor abundance or scarcity. The estimated coefficients merely indicate that the use of producer durables and the use of highly-skilled labour are significantly and positively related to trade performance, whereas the use of low and intermediate-skilled labour is significantly and negatively related to trade performance. In other words, manufacturing sectors in the Netherlands that make intensive use of producer durables and highly-skilled labour instead of low-skilled labour, are expected to have large positive net trade flows. These findings confirm the results of the factor content analysis for the sample of manufacturing sectors in Tables 5 and 6 . It is also in accordance with the results of Table 5 that the physical capital variable measuring structures is not significant for the manufacturing sectors, whereas the finding that the constant term is significantly negative is according to the above mentioned expectation. Moreover, the estimated equation is significant at the $5 \%$ level, whereas $75 \%$ of the variance of net exports is explained by the sector-specific factor inputs.

Table 7

Estimated indicators of trade-revealed factor endowments: net exports per sector adjusted for trade imbalance regressed on the sectoral input-output requirements, 1991

manufacturing sectors

all sectors

\begin{tabular}{lcc}
\hline constant & $-2,185$ & $\left(2.17^{\mathrm{a}}\right)$ \\
& $-146,187$ & -206 \\
low-skilled labour & $\left(3.07^{\mathrm{b}}\right)$ & $(0.17)$ \\
& $-159,634$ & 8,707 \\
intermediate-skilled labour & $\left(2.15^{\mathrm{a}}\right)$ & $\left(1.69^{\mathrm{a}}\right)$ \\
highly-skilled labour & 209,606 & $-38,244$ \\
& $\left(2.83^{\mathrm{b}}\right)$ & $\left(2.60^{\mathrm{b}}\right)$ \\
structures & 270,652 & $-14,506$ \\
& $(0.47)$ & $\left(2.23^{\mathrm{b}}\right)$ \\
producer durables & 706,595 & $-80,422$ \\
$\bar{R}^{2}$ & $\left(3.07^{\mathrm{b}}\right)$ & $\left(4.98^{\mathrm{c}}\right)$ \\
F-stat. & 0.75 & 180,755 \\
observations & $10.66^{\mathrm{c}}$ & $\left(4.07^{\mathrm{c}}\right)$ \\
& 17 & 0.24 \\
& 17 & $3.40^{\mathrm{b}}$
\end{tabular}

Notes: The absolute t-values are between brackets. The t-values are calculated by using a heteroscedasticity consistent covariance matrix. The superscipts $a, b$ and $c$ indicate a significant coefficient at the $10 \%, 5 \%$ and $1 \%$ level respectively.

Bowen and Sveikauskas (1992) show that if the vector of net exports $T_{i}$, which is adjusted for trade imbalance, is regressed on the input-output requirements (given by matrix $A$ ), the signs of the estimated coefficients indicate the revealed factor abundances of the respective production factors. In the introduction of this paper it has been noted that such a regression analysis is not theoretically correct. However, provided that all sectors of a country's economy are included in the regression analysis, this theoretical concern seems to be of little empirical importance. This implies that the positive and negative signs of the estimated coefficients can be used as reliable indicators of revealed factor abundance and scarcity, respectively, if all 
sectors are included in the regression analysis. This finding of Bowen and Sveikauskas validates the use of sector-specific factor inputs to explain sectoral trade performance in the empirical studies on Dutch trade performance and many other empirical studies (see e.g. Leamer, 1992, for an overview), although these studies failed to correct properly for trade imbalances. Another point of interest is that many of these studies only include a selection of sectors in the cross-section regression analysis. This may lead to incorrect conclusions, as will be shown below.

An important advantage of the cross-section regression analysis is that a positive (negative) sign of the estimated coefficients in the regression analysis reflects a trade-revealed factor abundance (scarcity) of the production factor (Bowen and Sveikauskas, 1992), while the factor content ratios that are found in the analysis at the country level in the previous section only indicate the rank order of factor abundances. To reveal the factor abundances and scarcities of each production factor, the adjusted net exports are regressed on the input-output requirements of low, intermediate and highly-skilled labour, and structures and producer durables. These input-output requirements represent the sector-specific factor inputs, which are regarded as the determinants of trade performance in many empirical studies that test one or another variant of the Heckscher-Ohlin model.

The last column of Table 7 shows the results of including all sectors in the regression analysis. The table shows that all estimated coefficients of the factor inputs are significant. ${ }^{30}$ Moreover, the estimated equation is significant at the $5 \%$ level with $\bar{R}^{2}$ equal to 0.24 . The positive signs of the estimated coefficients of low-skilled labour and producer durables in the regression equation for all sectors reveal that the low-skilled labour and producer durables are abundant in the Netherlands. On the contrary, the negative coefficients for intermediate-skilled labour, highly-skilled labour and structures indicate that these factors are scarce. These results of factor abundance and scarcity are completely in accordance with the conclusions that have been drawn in the previous section. This again confirms the value of the HOV model for analysing factor abundances.

Now it can be seen what happens if the signs of the regression analysis with the 17 manufacturing sectors only, are interpreted as indicators of factor abundance. In that case the conclusions on factor abundance will be incorrect and in some cases even opposite to the conclusions on factor abundance stated when all sectors are included in the regression analysis. This is due to the fact that the signs of the estimated coefficients of low-skilled labour, highly-skilled labour and structures are opposite to the signs of the estimated coefficients of these factors in the regression analysis when all sectors are included. Four out of five estimated coefficients of sector-specific inputs in the manufacturing sectors are significant,

30. Cörvers and Reininga (1996) show that these results are not dependent on the inclusion of the resource-intensive non-manufacturing sectors such as agriculture, fisheries, mining and quarrying, as is often stated (see e.g. Branson and Monoyios, 1977). Moreover, note that the constant term is negative as expected, although it is not statistically significant. 
which indicates their relevance for the trade performance of the manufacturing sectors.

Lastly, the estimated coefficients of the regression analysis for all sectors show that the sectors with larger input-output requirements of low-skilled labour and producer durables have on average larger net exports. Conversely, sectors with larger input-output requirements of intermediate and highly-skilled labour have on average smaller net exports. If the factor abundances of the human and physical capital endowments in the Netherlands change, the net exports of all sectors change. For example, a further rise of the factor abundance of lowskilled labour and a simultaneous fall of the factor endowment of highly-skilled labour, increases the net exports of sectors that make intensive use of low-skilled labour, whereas it decreases the net exports of the sectors that make intensive use of highly-skilled labour. ${ }^{31}$

However, the regression analysis for the manufacturing sectors only, shows that net exports are large for the manufacturing sectors that have large input-output requirements of highlyskilled labour and small input-output requirements of low-skilled labour. ${ }^{32} \mathrm{~A}$ rise of the factor abundance of low-skilled labour with a simultaneous fall of the factor abundance of highlyskilled labour in the Netherlands, may have a positive impact on the net exports of some manufacturing sectors, and a negative impact on the net exports of other manufacturing sectors. As stated above, whether there is a positive or a negative impact on the net exports of a particular manufacturing sector, depends on the input-output requirements of this sector relative to the input-output requirements of all other sectors of the economy. For example, textile, wearing apparel and leather, and fabricated metal products are low-skill manufacturing sectors (see Cörvers, 1997). These sectors will improve their trade performance when the relative factor endowment of low-skilled labour increases and the factor endowment of highlyskilled labour decreases. Conversely, the trade performance of high-skill intensive or technology-intensive manufacturing sectors such as chemicals, precision and optical instruments, and electrical machinery (Cörvers, 1997) will deteriorate in that case.

\section{Conclusions}

In this paper the HOV theorem is tested by measuring both true and trade-revealed factor endowments. Since the rank orders of factor abundance according to both methods of measurement are very similar, the HOV theorem is confirmed. It has also been illustrated that comparing the factor intensities of exports versus the factor intensities of imports is not the correct method to test the HOV theorem. The analysis of the Dutch factor endowments has

31. This is an implication of the so-called Rybczynski theorem of the HOV model. According to this theorem, in a world with two factors and two sectors, and with each sector producing one good that is sold at a constant price, an increase in the supply of a factor will lead to an increase in the output of the sector that uses that factor intensively and a decrease in the output of the other sector (see e.g. Leamer, 1984).

32. This only holds within the sample of the 17 manufacturing sectors. 
shown that the Netherlands has factor abundances in producer durables and low-skilled labour, whereas it has factor scarcities in intermediate-skilled labour, highly-skilled labour and structures. This implies that the Netherlands has a revealed comparative advantage in goods that are intensive in the use of producer durables and low-skilled labour, and a comparative disadvantage in goods that are intensive in the use of intermediate-skilled labour, highly-skilled labour and structures. A further disaggregation of the trade-revealed factor endowments according to the educational types of labour that are typical for the Netherlands, does not change these results, which confirms that the distinction between low, intermediate and highlyskilled labour is well chosen.

The factor content ratios for the Dutch manufacturing sectors are very different from the factor content ratios for the whole economy in the Netherlands, which highlights the relevance of including all sectors when drawing conclusions on trade-revealed factor abundances of human and physical capital. Moreover, regressing a measure of trade performance on sector-specific factor inputs must include all sectors to draw correct conclusions on factor abundance. This paper has shown that in the case of the Netherlands a partial analysis of the economy can lead to incorrect conclusions on factor abundance when using the HOV model.

However, the partial analysis of the manufacturing sectors by means of the HOV model indicates the contribution of sector-specific factor inputs to the trade performance of these sectors. The analysis reveals that in particular highly-skilled labour and producer durables are important factor inputs for the trade performance of the manufacturing sectors in the Netherlands, whereas the inputs of low and intermediate-skilled labour are negatively related to the trade performance of manufacturing sectors. For all sectors, including the manufacturing sectors, a further rise of the factor abundances of low-skilled labour and producer durables, and a simultaneous fall of the factor endowments of intermediate and highly-skilled labour, increase the net exports of sectors that make intensive use of low-skilled labour and producer durables, whereas they decrease the net exports of the sectors that make intensive use of intermediate and highly-skilled labour.

\section{References}

Bakker, G.P. Den (1993), Origin and Development of the Dutch National Accounts; in W.F.M. De Vries, G.P. Den Bakker, M.B.G. Gircour, S.J. Keuning and A. Lenson (eds.), The value Added of National Accounting, Netherlands Statistics, Voorburg/Heerlen, pp. 73-92.

Baldwin, R.E. (1971), Determinants of the Commodity Structure of US Trade, American Economic Review, Vol. 61, pp. 126-146.

Bowen, H.P., E.E. Leamer and L. Sveikauskas (1987), Multicountry, Multifactor Tests of the Factor Abundance Theory, American Economic Review, Vol. 77, pp. 791-809.

Bowen, H.P. and L. Sveikauskas (1992), Judging Factor Abundance, Quarterly Journal of Economics, Vol. 106, pp. 600-620. 
Branson, W.H. and N. Monoyios (1977), Factor Inputs in U.S. Trade, Journal of International Economics, Vol. 7, pp. 111-131.

Brecher, R.A. and E.U. Choudhri (1982), The Factor Content of International Trade without Factor Price Equalization, Journal of International Economics, Vol. 12, pp. 277-283.

CBS (1990), Maandstatistiek van de Buitenlandse Handel, Vol. 2, SDU, The Hague.

Clifton, D.S. and W.B. Marxsen (1984), An Empirical Investigation of the Heckscher-Ohlin Theorem, Canadian Journal of Economics, Vol. 17, pp. 32-38.

Cörvers, F. (1997), The Impact of Human Capital on Labour Productivity in Manufacturing Sectors of the European Union, Applied Economics, Vol. 29, pp. 975-987.

Cörvers, F. and A. De Grip (1997), Explaining Trade in Industrialized Countries by Country-specific Human Capital Endowments, Economic Modelling, Vol. 14, pp. 395-416.

Cörvers, F. and F.K. Reininga (1996), Analyzing Relative Factor Inputs of Dutch Exports: an application of the 1991 social accounting matrix for the Netherlands, National Accounts, Statistics Netherlands, Occasional Paper, No. NA-069, Voorburg.

CPB (1993), De Nederlandse Uitvoerprestatie sinds 1980, Working Paper, No. 45, Central Planning Bureau, The Hague.

Courakis, A.S. (1991), Labour Skills and Human Capital in the Explanation of Trade Patterns, Oxford Economic Papers, Vol. 43, pp. 443-462.

Deardorff, A.V. (1982), The General Validity of the Heckscher-Ohlin Theorem, American Economic Review, Vol. 72, pp. 683-94.

Deardorff, A.V. (1984), Testing Trade Theories and Predicting Trade Flows; in R.W. Jones and P.B. Kenen (eds.), Handbook of International Economics, Vol. 1, Elsevier, Amsterdam, pp. 467-517.

Fortune, J.N. (1976), The Distribution of Labor Skills and the Commodity Composition of International Trade, Weltwirtschaftliches Archiv, Vol. 112, pp. 580-583.

Forstner, H. (1985), A Note on the General Validity of the Heckscher-Ohlin Theorem, American Economic Review, Vol. 75, pp. 844-849.

Grossman, G.M. and E. Helpman (1991), Innovation and Growth in the Global Economy, MITPress, Cambridge, Massachusetts, London, England.

Gujarati, D.N (1988), Basic Econometrics, McGraw-Hill, Singapore.

Hamilton, C. and L.E.O. Svensson (1984), Do Countries' Factor Endowments Correspond to the Factor Contents in their Bilateral Trade Flows?, Scandinavian Journal of Economics, Vol. 86, pp. 84-97. Helpman, E. (1984), The Factor Content of Foreign Trade, Economic Journal, Vol. 94, pp. 84-94. Hulsman-Vejsová, M. and K.A. Koekkoek (1980), Factor Proportions, Technology and Dutch Industry's International Trade Patterns, Weltwirtschaftliches Archiv, Vol. 116, pp. 162-177.

James, A.M. and B.T. Elmslie (1996), Testing Heckscher-Ohlin-Vanek in the G-7, Weltwirtschaftliches Archiv, Vol. 132, pp. 139-159.

Judge, G.G, C.R. Hill, W.E. Griffiths, H. Lütkepohland and T. Lee (1980), Theory and Practice of Econometrics, John Wiley \& Sons, New York

Katrak, H. (1973), Human Skills, R and D and Scale Economies in the Exports of the United Kingdom 
and the United States, Oxford Economic Papers, Vol. 25, pp. 337-360.

Koekkoek, K.A., J. Kol and L.B.M. Mennes (1978), De Nederlandse Industrie: concurrentievermogen, comparatieve voordelen en goederensamenstelling van de internationale handel (II), Economisch Statistische Berichten, Vol. 63, pp. 744-746.

Koekkoek, K.A. and L.B.M. Mennes (1984), Revealed Comparative Advantage in Manufacturing Industry: The Case of the Netherlands, De Economist, Vol. 132, pp. 30-48.

Konijn, P.J.A. (1994), The Make and Use of Commodities by Industries, University of Twente, Enschede.

Konijn, P. and S. de Boer (1993), Een Homogene Input-Outputtabel voor Nederland, 1990,

Department of National Accounts, Central Bureau of Statistics, Voorburg.

Leamer, E.E. (1980), The Leontief Paradox Reconsidered, Journal of Political Economy, Vol. 88, pp. 495-503.

Leamer, E.E. (1984), Sources of International Comparative Advantage, Theory and Evidence, MIT Press, Cambridge, Massachusetts.

Leamer, E.E. (1992), Testing Trade Theory, NBER, Working Paper, No. 3957, Cambridge, Massachusetts.

Leamer, E.E. and H.P. Bowen (1981), Cross-section of the Heckscher-Ohlin Theorem: Comment, American Economic Review, Vol. 71, pp. 1040-1043.

Leontief, W. (1953), Domestic Production and Foreign Trade: The American Capital Position Reexamined, Proceedings of the American Philosophical Society, Vol. 97, pp. 332-349.

Maskus, K.E., C.D. Sveikauskas and A. Webster (1994), The Composition of the Human Capital Stock and its Relation to International Trade: Evidence from the US and Britain, Weltwirtschaftliches Archiv, Vol. 130, pp. 50-76.

OECD (1987), Structural Adjustment and Economic Performance, Paris.

OECD (1992, 1993, 1995), Education at a Glance, Paris.

Reininga, F.K. (1994), De Relatieve Factorintensiteit van de Nederlandse Export, Economisch Statistische Berichten, Vol. 79, pp. 898-904.

Stern, R.M. and K.E. Maskus (1981), Determinants of the Structure of U.S. Foreign Trade, Journal of International Economics, Vol. 11, pp. 207-224.

Timmerman, J.G. and P.J. Van De Ven (1994), A Social Accounting Matrix for The Netherlands, Concepts and Results, National Accounts, Statistics Netherlands, Occasional Paper, No. NA-068, Voorburg/ Heerlen.

United Nations $(1968,1993)$, A System of National Accounts, United Nations, Series F, No. 2, Rev. 3 , New York.

Vanek, J. (1968), The Factor Proportions Theory: The N-Factor Case, Kyklos, Vol. 21, pp. 749-754.

Webster, A. (1993), The Skill and Higher Educational Content of UK Net Exports, Oxford

Bulin of Economics and Statistics, Vol. 55, pp. 141-159.

Webster, A. and M. Gilroy (1995), Labour Skills and the UK's Comparative Advantage with its European Union Partners, Applied Economics, Vol. 27, pp. 327-342.

White, H. (1980), A Heteroskedasticity-Consistent Covariance Matrix and a Direct Test for 
Heteroskedasticity, Econometrica, Vol. 48, pp. 817-838. 


\section{Appendix A \\ Classification of sectors}

The analysis in the paper uses a classification of 40 sectors. This sector classification is listed below.

Agriculture and fisheries

1. Agriculture, horticulture and forestry

2. Fishing

Mining and quarrying

3. Extraction of crude petroleum

4. Other mining and quarrying

Manufacturing

5. Food and beverages

6. Tobacco

7. Textile

8. Wearing apparel

9. Leather

10. Wood and furniture

11. Paper and paper products

12. Publishing and printing

13. Petroleum refineries

14. Chemicals

15. Construction materials

16. Basic metals

17. Fabricated metal products

18. Machinery and equipment

19. Electrical machinery and apparatus

20. Transport equipment

21. Precision and optical instruments

Utilities and construction

22. Electricity, gas and water supply

23. Construction

Trade, hotels, repair of consumer goods

24. Wholesale, retail trade en repair

25. Hotels and restaurants

Transport, storage and communication

26. Water and air transport

27. Other transport activities

28. Communication

Commercial services

29. Banking

30. Insurance

31. Real estate activities 
32. Other business activities

Other services

33. Public administration and social security

34. Defence

35. Education

36. Social work

37. Health

38. Cultural, sporting en recreational activities

39. Other services

40. Personnel in paid employment 


\section{Appendix B \\ Methodology of data generation ${ }^{33}$}

The method of calculating factor contents is largely based on the use of input-output (I-O) tables. The human capital content calculations in this paper are based on Social Accounting Matrices (SAMs) of Statistics Netherlands, which contain detailed data on educational levels of labour inputs per industry (see Timmerman and Van de Ven, 1994). This data set is drawn from the Labour Accounts (LA) and is consistent with the input-output data of the National Accounts (NA). The latter accounts are also constructed by Statistics Netherlands. This appendix first briefly discusses the methodology behind the input-output (I-O) tables, social accounting matrices (SAMs) and supply and use tables from which the data are drawn. It also discusses how we have dealt with two well-known methodological problems of I-O tables, i.e. the homogeneity of $\mathrm{I}-\mathrm{O}$ tables and the production technology of imports, to make the I-O framework suitable for calculating the factor content of production, exports and imports. Next, the valuation of $\mathrm{I}-\mathrm{O}$ tables will be briefly touched upon. Finally, the construction of a consistent set of labour and capital data will be discussed.

\section{Input-output tables}

I-O tables are widely used in national accounting. They have proved to be a suitable framework for utilising production statistics from different sources. ${ }^{34}$ However the intra-industry structure of I-O tables does not match the structure of the basic data. A company typically knows the type of products purchased and produced, but does not usually know in what category statisticians classify the companies with which it does business. Consequently, since 1968 the System of National Accounts (SNA) has advocated the use of 'supply and use' tables as a balancing device (United Nations, 1968). The use table shows commodity usage by using industry and final demand category. The supply table gives a corresponding picture of the supply of commodities, distinguishing between the supplying industries. Since 1987, Statistics Netherlands has employed supply and use tables to arrive at accurate estimates of total production (GDP). However, Statistics Netherlands continues to construct I-O tables because they are still very much valued as an analytical tool. In contrast to the practice before 1987, these I-O tables are now derived indirectly from the supply and use tables (see e.g. Konijn, 1994).

\section{Social accounting matrices}

SAMs offer a very convenient expedient to combine the description of the production process in supply and use tables with detailed information on other aspects of the economic process. This is confirmed in Chapter 20 of the 1993 System of National Accounts (SNA), on SAMs: ".. A SAM is defined here as the presentation of SNA accounts in a matrix which elaborates the linkages between a supply and use table and institutional sector accounts.." (UN, 1993, p.

33. This appendix is almost literally taken from Cörvers and Reininga (1996).

34. Den Bakker (1993) describes the extensive use of the I-O table by Statistics Netherlands until 1987. 
461). Because a SAM may be considered as an extension of an I-O table incorporating the distribution and use of income, the analytical applications of SAMs and I-O tables are largely the same. Basically, both SAMs and I-O tables are based on the assumption of a linear relation between an endogenous (target) variable, e.g. (aggregate) output and employment, and the exogenous part of the SAM, e.g. government spending and exports. In contrast to I-O analysis, however, the SAM model is 'closed' with respect to income distribution and income use.

As stated above, the Dutch SAMs contain supply and use tables instead of an I-O table to describe the production process. Inverting this SAM for our analytical purposes implicitly leads to the mechanical construction of an industry-by-industry I-O table (see below) based on the 'assumption of fixed industry sales structures' (Konijn, 1994, pp. 110-111). According to this assumption, each industry has its own specific sales structure irrespective of its product mix. In other words, it is assumed that all products of a specific industry are sold in exactly the same proportion to other industries, households, the government, and other countries. As this assumption is rather implausible, using the SAM would lead to a distorted mapping of final demand to the use of production factors. Consequently, we have used an industry-by-industry I-O table for our analysis. This table is derived by Statistics Netherlands from supply and use tables, using additional information on commodity flows between industries. The SAM provides detailed additional data on the educational levels of the labour used by industry. These data are consistent with the data from the industry-by-industry I-O table. This paper therefore utilises one of the major advantages of SAMs as a statistical tool: the balancing of statistical information from various sources.

\section{The homogeneity of the I-O table}

An I-O table reflects the output of commodities on the one hand, and the intermediate goods, labour, and capital used to produce these commodities on the other hand. In many cases a company, and therefore an industry defined as a group of companies engaged primarily in the same activity, does not produce only a single product. In addition to its primary, characteristic product, it may produce one or more secondary, non-characteristic products. ${ }^{35}$ If companies are categorised in the various industries in the I-O table solely on the basis of their primary products, without taking specific account of the problem of secondary products, the result is an 'industry-by-industry table'. In a 'commodity-by-commodity' table the secondary products are separated from primary products whenever possible, and reallocated to other industries to obtain a more or less homogeneous table. ${ }^{36}$

35. Two cases can be distinguished (see Konijn, 1994, pp. 60-64): 1. Subsidiary products: the products are technically unrelated, so that it is in principle possible to attribute inputs to the various products; 2. By-products and joint products: the primary and secondary product(s) are produced simultaneously, and joint inputs cannot be attributed to the various products. Where one product can be considered to be the primary product, the others are considered by-products. Where this is not possible, all are considered as joint products.

36. Statistics Netherlands has compiled such a commodity-by-commodity table for 1991 (Konijn and De Boer, 1993). 
However, there are as yet no labour market data consistent with the categorisation of productive activities in the commodity-by-commodity table. As a consequence, the test has to be conducted using the less appropriate $60 \times 60$ industry-by-industry table. This table had to be aggregated to a corresponding $40 \times 40$ table to make it possible to use the detailed labour data in the SAM.

\section{Production technology of imports}

Because no data are available on the production techniques actually used in the producing countries, the analysis discussed here has to be based on a number of assumptions with regard to the production technology of imports. In line with one of the postulates of the Heckscher-Ohlin theory, we follow the 'equal technology' assumption, i.e., that the production technology of competitive imports is assumed to be equal to the production technology in competing industries in the importing country. ${ }^{37}$

\section{Valuation of I-O tables}

According to SNA'93, I-O tables can be valued in (i) basic prices, (ii) producer prices, and (iii) purchasers' prices. It is important in testing the Heckscher-Ohlin theory to use basic prices as only this valuation excludes the distorting effect of government taxes and subsidies on products. Valuations in basic prices can be considered to reflect relative abundances of production factors more accurately than other valuation methods. For our analysis we used the 1991 I-O table for the Netherlands valued in basic prices.

\section{Remarks on the labour data used}

The Department of Labour Statistics of Statistics Netherlands is responsible for collecting and analysing labour market data. This department has constructed valuable employment data, splitting total employment data in full-time equivalents for the various industries into 7 different subtotals based on the levels of education of the employees: (i) primary education (BO), (ii) Lower General Secondary Education (MAVO), (iii) Preparatory Vocational Education (VBO), (iv) Higher General Secondary Education and Pre-University Education (HAVO/VWO), (v) Intermediate Vocational Education (MBO), (vi) Higher Vocational Education (HBO), and (vii) University Education (WO).

However, primarily because of some minor classification differences, the employment data do not fully match the data that are used in the National Accounts Department. A balancing process was therefore required, using a Social Accounting framework. This resulted in a consistent set of National Accounts and labour market data for 40 industries. Moreover, the Social Accounting Matrix supplies corresponding details on the wages for total employment in full-time equivalents per industry and for the seven educational categories. Thus the labour data offers ample opportunities to derive proxies for the human capital used in producing goods and services in the Netherlands. Three well-known methods to assess the volume of

37. As has been argued above, most trade takes places between industrialised countries, which are expected to have relatively similar input-output coefficients. 
human capital inputs are: (i) valuation based on years of initial education, (ii) valuation based on wages paid per educational level and per industry, and (iii) valuation based on the average wage per educational level of the total economy. The last of these avoids the possible effect of industry-specific elements but, as Reininga (1994) has shown, the choice of valuation method does not influence the outcome of the factor content calculations for the Netherlands. In our analysis we have adopted valuation method (ii), since this method values human capital in monetary units (just like physical capital, see below) and at the most disaggregated level.

Remarks on the capital data used

The capital input is assumed to be equal to depreciation costs. However, in the Netherlands no depreciation data detailed at the level of our 40x40 I-O table are available. In line with standard Leontief I-O theory regarding the constancy of I-O coefficients, the available data on depreciation for 23 industries are disaggregated on the basis of output data to the 40 industries of the I-O table. Two types of physical capital are distinguished: producer durables, including machinery and (transport) equipment, and structures, which covers residential construction, non-residential construction and other construction. 


\section{Appendix C}

\section{Data of relative true factor endowments}

Table C. 1 shows the relative true factor endowments of 21 OECD countries, including the Netherlands. Relative to the other OECD countries, the Netherlands takes an intermediate position in the rank orders of all relative true factor endowments mentioned in Table 1, except for the low ranking of the structures component of physical capital.

Table C.1

Relative true factor endowments of low (LSW), intermediate (ISW) and highly-skilled (HSW) labour, producer durables (PRO) and structures (STR) per country, 1990

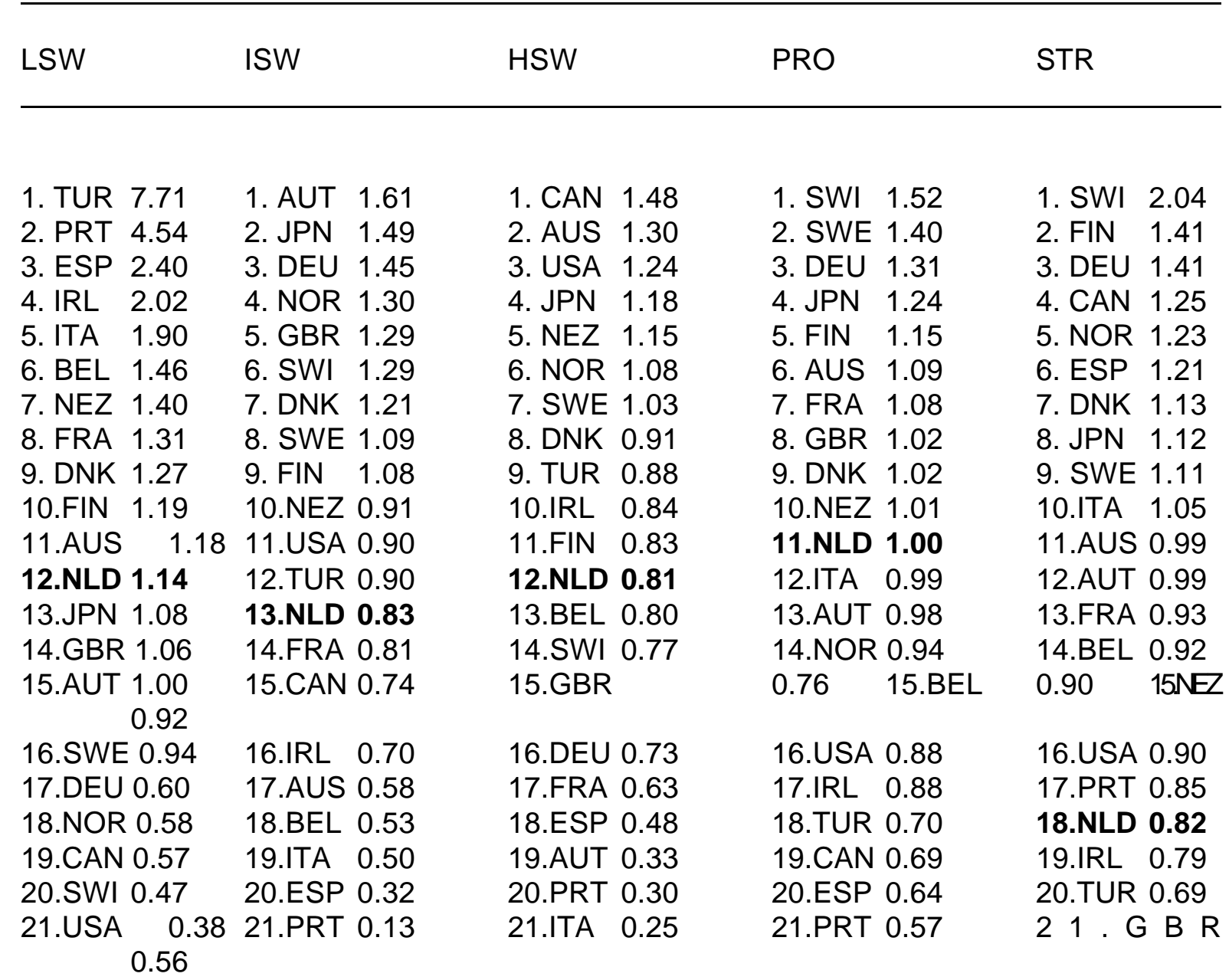

Sources: Penn World Table (Mark 5.6); Education at a Glance (OECD, 1992, 1993).

Notes: German figures refer to the former Federal Republic of Germany; German levels of educational attainment are from 1989; Japanese levels of educational attainment are from 1987.

Abbreviations of the countries:

AUS = Australia; AUT = Austria; BEL = Belgium; CAN = Canada; DEU = Germany; DNK = Denmark; ESP = Spain; FIN = Finland; FRA = France; GBR = Great Britain; IRL = Ireland; ITA = Italy; JPN = Japan; NEZ = New Zealand; NLD = Netherlands; NOR = Norway; PRT = 
Portugal; SWE = Sweden; SWI = Switzerland; TUR = Turkey; USA = United States 